\title{
THE IMPORTANCE OF BANK'S REPUTATION IN THE SELECTION OF BANKING PRODUCTS IN THE OPINION OF MIDDLE POMERANIAN FARMERS
}

\author{
Anna Rosa ${ }^{凶}$ \\ Politechnika Koszalińska
}

\begin{abstract}
Farmers, when choosing a bank whose services they want to use, are guided by various factors. The purpose of the research conducted was to select the most essential factors that determine the choice of a bank and an identification of connections between opinions on a bank (its reputation) and the selected features that characterize farmers from the Middle Pomeranian region. The primary data obtained in the course of the empirical field research conducted and a multidimensional correspondence analysis were used in the realization of the objective accepted. The following constituted the set of operands: the status and acreage of the farm, the type and the value of production, sex, age and education of the person in charge of the farm. As is evident from the research conducted, the opinion on a bank (its reputation) was the most essential determinant indicated in the selection of banks by farmers. The analysis demonstrated among others that those farmers polled who think that the opinion on the bank constitutes an important cause in the selection of banking products and services are in aged below 45, they possess secondary agricultural education and run farms with plant and animal production.
\end{abstract}

Key words: farmer, banking products and services, opinion on a bank, reputation and image, the Middle Pomerania

\section{INTRODUCTION}

These days, use of banking services is becoming almost a necessity. Banking products and services are commonly used in various areas of our personal and professional lives: from the depositing of money from earnings, taking out credit liabilities and payment of bills and making purchases on the Internet using debit cards.

Farmers are included in a segment of those customers for whom banks have prepared and offer banking products that are adequately adapted to their needs. The microeconomic features of farms including social and personal, as well as behavioural features decide about the connection of farmers with banks (Kata, 2011).

Only a few years ago, farmers were included in the least banked groups in the Polish society, yet this situation has changed and, according to the research conducted by AGRIBUS in 2015 and commissioned by BZWBK leasing, 92\% of farmers in Poland already use various banking products. Almost every fourth farmer in Poland (24\%) finances his investments with the use of cash loans, and every tenth farm in Poland (10\%) uses bank investment financing ${ }^{1}$.

It is evident based on a review of the literature that those criteria and motives by which farmers are guided when choosing bank from whose services they want to

\footnotetext{
${ }^{1}$ Within the framework of the research of Martin\&Jacob commissioned by BZ WBK Leasing in total 1,005 direct computer-aided interviews (CAPI) were realized. They took place on farms. The research was realized with a representative sample of farms from all over Poland who possess at least 15 hectares of agricultural lands, the number of which is 205,271 . The interviews were conducted with adult people, owners of farms who declared that they take decisions on their farms.
}

\footnotetext{
${ }^{\otimes}$ dr Anna Rosa, Katedra Finansów, Politechnika Koszalińska, ul. Kwiatkowskiego 6e, 75-343 Koszalin, Poland, e-mail: anna. rosa@tu.koszalin.pl
} 
use are a very individual issue, one that is subjective to a great extent and dependent on the customer's feelings. The factors that have an influence on the selection of a financial institution may include following: the bank's credibility, a wide range of services, competitive terms and conditions in relation to interests and fees, professionalism and promptness of service, location and availability of the bank, prestige of bank, previous contacts with the bank, simple procedures, comprehensive customer service, chain of institutions and cash machines, professional financial consultancy, promptness of settlements, offer of Internet banking and bank advertisement (Kata, 2003).

It is evident based research by Alessandrini that the proximity of the bank is an essential factor in the selection of a bank. It is a particularly essential determinant for credit relations (Alessandrini et al., 2009). This is confirmed with research conducted in south-east Poland. It shows that farmers attach great significance to the spatial proximity and a direct personal contact with the bank (Kata, 2010). The credibility of the bank as well as its location and availability also have an influence on the selection of a bank to a great extent. Further factors include the efficiency of service, the order delivery time and wide range of services (according to the research of Zajacc, 2010). In the case of the selection for the sources of financing according to the research commissioned by BZ WBK Leasing, the following were the main selection criteria for almost a half of farmers in Poland: flexible conditions of repayment, availability of the branch and the sales chain. Additionally, over $1 / 4$ of the respondents pointed to procedures understood as the amount of documents required and the investment security.

The research carried out by Rosa with Middle Pomeranian farmers was to indicate those factors that are essential to the respondents and by which they are guided when choosing a bank whose services they intend to use. Farmers had the following criteria to choose from: an opinion about the bank (its reputation and reliability), long-standing cooperation, convenient location of the bank and parking spaces, lack of another bank in the area, the opening hours of the branch, the bank's financial condition, a friendly customer approach, flexibility and taking into consideration the customer's individual needs, the range of the services offered, the speed and promptness of settlements, the amounts of fees and commissions, advertising, available advertising materials, the number of service stands and clear marking of these.
When determining the degree of importance, farmers could select several variants of answers and rank them to assign the degree of significance for a given reason for their choice of the bank ( 1 meant a little important feature while 5 meant a very important feature). When analyzing the distribution of ranks assigned to the categories of answers, it was found that the most frequently (the highest sum of ranks for the individual variants of answers) indicated reasons for the choice of the bank (both by the customers of commercial banks and cooperative banks) included the opinion about the bank and the bank's credibility. The farmers pointed to the long-standing cooperation with the bank - as their habit, the speed of settlements, the promptness, as well as the amounts of fees and commissions (Rosa, 2014).

The weight of reputation is frequently underestimated by the decision-makers of banks as it is extremely difficult to evaluate it, and it refers to the emotional sphere (confidence). It takes years for a bank to work for a good reputation, and it may lose it within a few moments; hence, the question of proper and effective management of the reputation risk is so essential (Paxford, 2010). According to M.K. Saxton, reputation constitutes a specific image of an organization over a time span seen with the eyes of its stakeholders and represented in their thoughts and words (Saxton, 1998). B.A. Neville, S.J. Bell and B. Mengüç believe that reputation involves a comprehensive assessment of the organization's image in the perspective of the stakeholder's personal values (Neville et al., 2005). An opinion about a bank (its reputation) undoubtedly exerts an influence on customers' behaviours and decisions because the service as offered by the bank is intangible.

The purpose of the present study is to verify interrelations between the opinion about the bank and the selected features that characterize farmers from the Middle Pomeranian region.

\section{SOURCE MATERIAL AND RESEARCH METHODOLOGY}

Original research material was used in the study. It was obtained in the course of the empirical field research conducted with farmers from the Middle Pomeranian region. This is an area that covers Zachodniopomorskie and Pomorskie voivodeships (the former Koszalińskie and Stupskie voivodeships) (Zawadzka, 2008). The Koszalińki Subregion consists of the following districts: 
Białogard, Drawsko Pomorskie, Kołobrzeg, Koszalin, Sławno, Szczecinek, Świdwin, Wałcz as well as a town with the district status: Koszalin. The Subregion of Słupsk covers the following districts: Bytów, Człuchów, Lębork, Słupsk a town with the district status: Słupsk.

Snowball sampling was used as the method for the selection of respondents. The study attempted to conduct 300 interviews with farmers leading domestic farm in the Middle Pomerania. The research was realized in 2012 with the use of a diagnostic survey, and the questionnaire form constituted its research tool. To distinguish the features of those farmers for whom the opinion about a bank was important (when choosing a financial institution), a multidimensional correspondence analysis was used, and the required calculations were performed with Statistica and Excel computer software.

The correspondence analysis is a descriptive and explorative technique which provides information on the nature of connections between the categories of the qualitative variables analysed (Stanisz, 2015). This is not a confirmatory technique whose aim is to confirm or not research hypotheses, but precisely it is an explorative method which aims at discovering the connections and presentation of a data structure (Greenacre, 1992). The method is characterized by a wide range of applications and the possibility of a graphical presentation of research results. The results obtained by using it are clear, which undoubtedly facilitates their interpretation. Apart from that, it enables an accurate recognition of the co-occurrence of the categories of variables or objects which are measured on nominal and ordinal scales (Greenacre, 1984).

The procedure of the correspondence analysis was performed in the following steps (Machowska-Szewczyk and Sompolska-Rzechuła, 2012; Stanimir, 2005):

1. Determination of the Burt matrix. This matrix is the result of the operation: $\mathbf{B}=\mathbf{Z}^{\mathrm{T}} \mathbf{Z}=\left[b_{i j}\right]_{j \times j}$ where: $\mathbf{Z}=$ $\left[Z_{1}, Z_{2}, \ldots, Z_{Q}\right]-$ a compound matrix of tags for $n$ objects and $Q$ features, $J=\Sigma^{Q}{ }_{q=1} J_{q}$, - the feature $q$ category number. The Burt matrix is symmetric and it consists of blocks. On the main diagonal, there are diagonal matrixes including the numbers of the occurrences for feature categories and, apart from the main diagonal, there are contingency tables that correspond to two different features that include the numbers of objects with the established categories of these two features.
2. Determination of the real space dimension of the co-occurrence of the categories of variables $K$ according the following formula:

$$
K=\sum_{\mathrm{q}=1}^{Q}\left(J_{q}-1\right)
$$

where: $J_{q}$ - number of the category of feature $q$ ( $q=$ $1,2 \ldots, Q), Q$ - number of features.

3. A verification as to what extent the space's eigenvalues with a lower dimension explain the total inertia. Accordig to the Greenacres criterion main inertia that are greater than $1 / Q$ are accepted as significant for research. According to Greenacre, the optimal dimension $K^{*}$ of space is $K^{*}=\max \left\{k \in\{1, \ldots, K\}: \lambda_{k}>\frac{1}{Q}\right\}$.

Greenacre also provides an ,improvement” method for those coordinates that are received as a result of a transformation of the Burt matrix according to the following formula: $\widetilde{\mathrm{F}}=\mathrm{F}^{*} \Gamma^{-1} \bar{\Lambda}$, where: $\bar{\Lambda}$ - diagonal matrix of the first $K^{*}$ eigenvalues modified according to the following formula: $\tilde{\lambda}_{k}=\left(\frac{Q}{Q-1}\right)^{2}\left(\sqrt{\lambda_{k}}-\frac{1}{Q}\right)^{2}$ - matrix of the first $K^{*}$ coordinates of the category from matrix $\mathbf{F}$.

4. Use of the Ward's method in feature category classification. Selected methods of classification can be used in a graphical presentation of the co-occurrence of features in the space with a dimension being greater than three. The categories of all the features analyzed need to be determined as objects, while the values of the coordinates of each category projecting are variables. Classification methods also are useful when the number of all the variants of features is high and the scattering of points in the chart does not allow one to explicitly distinguish classes. One of the most popular agglomerative method: the Ward's method (Ward, 1963; Panek, 2009) that is considered to be very effective (Malina, 2004) is frequently used in the classification of categories.

5. A graphical presentation of the connections of the categories of variables in a two- or three-dimensional space.

In the study, the following variables and their categories were accepted when assigning appropriate denotations to them:

1. opinion about the bank (reputation) - OPINIA (1 very important or important cause, 0 - less important), 
2. status of the farm - ST (T - commercial, NT - non-commercial),

3. farm acreage - POW $(<=15-$ smaller from or equal to the median, i.e. 15 ha, $>15$ - greater than the median, i.e. 15 ha),

4. production type - R_PR ( $\mathrm{R}$ - plant, $\mathrm{Z}$ - animal, $\mathrm{M}$ - mixed),

5. value of production - WART_PR $(1-$ below PLN 29,999, 2 - PLN 30,000-49,999, 3 - PLN 50,00099,999, 4 - PLN 100,000-500,000, 5 - over PLN $500,000)$

6. sex of the person in charge of the farm - PL (K woman, $\mathrm{M}-\operatorname{man}$ ),

7. age of the person in charge of the farm - WIEK $(<=45$ - not higher than 45 years, $>45$ - higher than 45 years, 45 years old - respondents' age average),

8. education of the person in charge of the farm WYKSZ (W - higher, SR - secondary agricultural, $<=\mathrm{S}-$ at most secondary).

The first feature was recognized as dependent and the subsequent ones as independent. The features were adequately categorized: in the case of a dependent feature, one was assigned for a reply with rank 5 or 4 , and 0 - for lower ranks. For the features accepted in the research as independent ones, their distributions were examined and a median was accepted for categorization: in the case of a strong asymmetry of distribution, or an average value if the distribution of the feature was characterized by a weak asymmetry.

\section{RESEARCH RESULTS}

In the research into the connections between the opinion on the bank and the selected features that are characteristic for farmers from the Middle Pomeranian region, a Burt matrix was obtained with the dimensions of $21 \times 21$. The dimension of the real space for the cooccurrence of answers to the questions was 13. Further, a verification was performed of how space eigenvalues with lowers dimension explain total inertia. The optimal projecting dimension of the variables category spaces is selected in accordance with the Greenacres criterion on the basis of the condition: $\lambda_{k}>1 / Q$, where $Q$ - the number of features. Table 1 presents eigenvalues and

Table 1. Singular values and eigenvalues as well as the explanation degree of total inertia

Tabela 1. Wartości osobliwe i wartości własne oraz stopień wyjaśnienia całkowitej bezwładności

\begin{tabular}{ccccc}
\hline \multirow{2}{*}{$\begin{array}{c}\text { Number of dimensions } \\
\text { Liczba wymiarów }\end{array}$} & Values - Wartości & \multicolumn{2}{c}{ Percent - Procent } \\
\cline { 2 - 5 }$K$ & strange - osobliwe & eigenvalues - własne & intertia - bezwładności & cumulative - skumulowany \\
$\gamma_{k}$ & 0.506 & $\gamma_{k}$ & $\lambda_{k} / \lambda$ & 15.739 \\
\hline 1 & 0.427 & 0.256 & 15.739 & 26.961 \\
3 & 0.391 & 0.182 & 11.222 & 36.392 \\
4 & 0.373 & 0.153 & 9.431 & 44.948 \\
5 & 0.363 & 0.139 & 8.556 & 53.035 \\
6 & 0.353 & 0.131 & 8.087 & 60.718 \\
7 & 0.349 & 0.125 & 7.683 & 68.228 \\
8 & 0.336 & 0.122 & 7.51 & 75.174 \\
9 & 0.317 & 0.113 & 6.946 & 81.368 \\
10 & 0.305 & 0.101 & 6.194 & 87.087 \\
11 & 0.296 & 0.093 & 5.719 & 92.465 \\
12 & 0.256 & 0.087 & 5.378 & 96.489 \\
13 & 0.239 & 0.065 & 4.024 & 100 \\
\hline
\end{tabular}

Source: own calculations.

Źródło: obliczenia własne. 
singular values as well as the degree of the explanation of total inertia were presented.

Using the Greenacre criterion in the research, the value was obtained which points to space $R^{5}$ which, in spite of the reduction of the projecting dimension, maps fairly accurately the distances between those points that represent the individual feature categories. The "elbow" criterion is another method to determine the number of eigenvalues which indicate those coordinates which are essential for projecting onto a lower dimension space. The use of the elbow criterion points to a possibility to analyze the connections of feature categories in three or four dimensions $\left(R^{3}\right.$ or $\left.R^{4}\right)$.

Based on Figure 1, it can be found that so-called elbow is located precisely for $k=5$. Therefore, an analysis of connections between the feature categories will take place in the three-dimensional space, which explains $53 \%$ of total inertia.

As another step, a modification of eigenvalues was carried out using the Greenacres proposal (Table 2).

After a modification of eigenvalues, the presentation of the co-occurrence of feature categories will be presented in $R^{2}$ and $R^{3}$, where the degree of the explanation of inertia is $55.6 \%$ and $72.3 \%$ respectively.
A graphical presentation of the results of an analysis of correspondence in two-dimensional space is provided in Figure 2.

To indicate connections between the categories of the features examined, a dendrogram obtained with the Ward's method was also used.

On the basis of the presentation of the results in Figure 2 and in the dendrogram (Fig. 3), it can be found that the factor that is decisive for the selection of a bank, is the opinion about the bank (its reputation and credibility), which is essential for those farmers who are aged below 45 and run farms with plant production. Among those people who take into account an opinion about the bank when choosing banking products and services, there were also farmers with agricultural secondary education, who deal with animal production on the farm.

Furthermore, the analysis demonstrated that the opinion about the bank and its reputation is not an essential determinant in the selection of a specific bank for farmers aged over 45 years (chiefly men) with at most secondary education, who run mixed type production, and who gain on their farms a production value in the range of PLN 30-50 thousand. It also evident from the analysis carried out that women with university

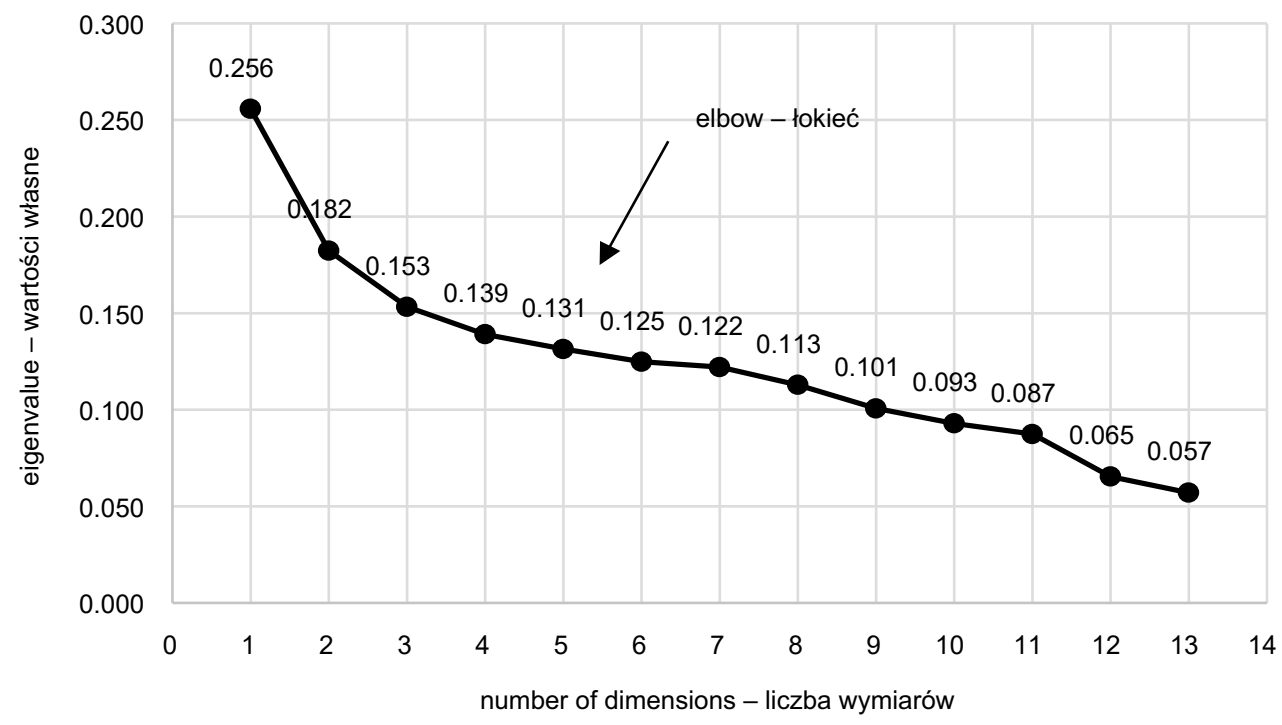

Fig. 1. Chart of eigenvalues Source: own calculations.

Rys. 1. Wykres wartości własnych

Źródło: obliczenia własne. 
Rosa, A. (2016). The importance of bank's reputation in the selection of banking products in the opinion of Middle Pomeranian farmers. J. Agribus. Rural Dev., 2(40), 399-406. DOI: 10.17306/JARD.2016.43

Table 2. Modified singular values and eigenvalues as well as the explanation degree of total inertia

Tabela 2. Zmodyfikowane wartości osobliwe i wartości własne oraz stopień wyjaśnienia całkowitej bezwładności

\begin{tabular}{ccccc}
\hline \multirow{2}{*}{$\begin{array}{c}\text { Number of dimensions } \\
\text { Liczba wymiarów }\end{array}$} & $\begin{array}{c}\text { Values }- \text { Wartości } \\
\text { własne } \\
\lambda_{k}\end{array}$ & $\begin{array}{c}\text { intertia } \\
\text { bezwładności } \\
\lambda_{k} / \lambda\end{array}$ & $\begin{array}{c}\text { Percent }- \text { Procent } \\
\text { wartości własnych }\end{array}$ & $\begin{array}{c}\text { cumulative } \\
\text { skumulowany } \\
\tilde{\lambda}_{k}\end{array}$ \\
\hline 1 & 0.435 & 0.189 & 34.104 & 34.104 \\
2 & 0.345 & 0.119 & 21.462 & 55.566 \\
3 & 0.305 & 0.093 & 16.706 & 72.272 \\
4 & 0.283 & 0.080 & 14.456 & 86.728 \\
5 & 0.271 & 0.074 & 13.272 & 100.000 \\
\hline
\end{tabular}

Source: own calculations.

Źródło: obliczenia własne.

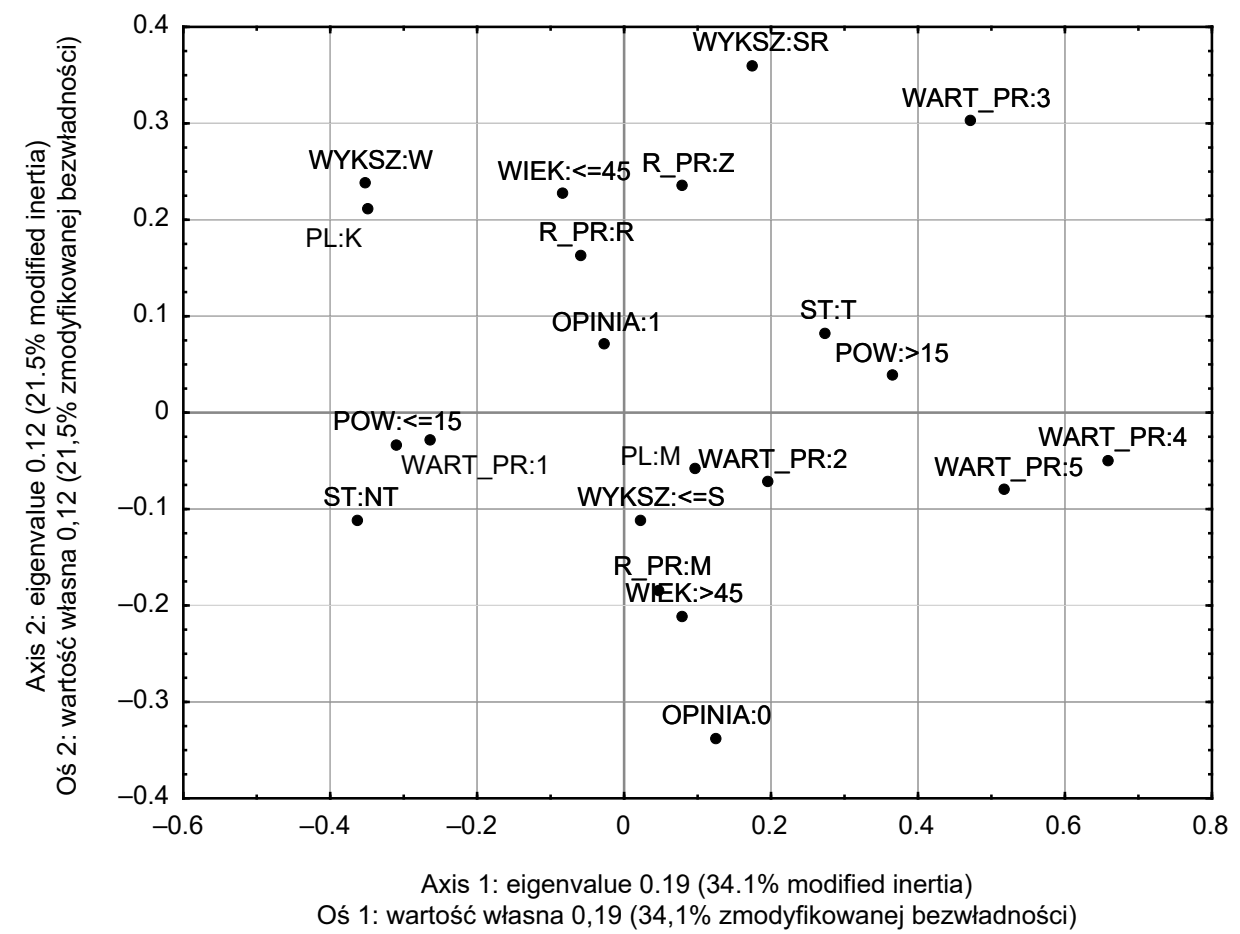

Fig. 2. Presentation of the results for the connections of feature categories in two-dimensional space

Source: own calculations.

Rys. 2. Prezentacja wyników powiązań kategorii cech w przestrzeni dwuwymiarowej Źródło: obliczenia własne. 
Rosa, A. (2016). The importance of bank's reputation in the selection of banking products in the opinion of Middle Pomeranian farmers. J. Agribus. Rural Dev., 2(40), 399-406. DOI: 10.17306/JARD.2016.43

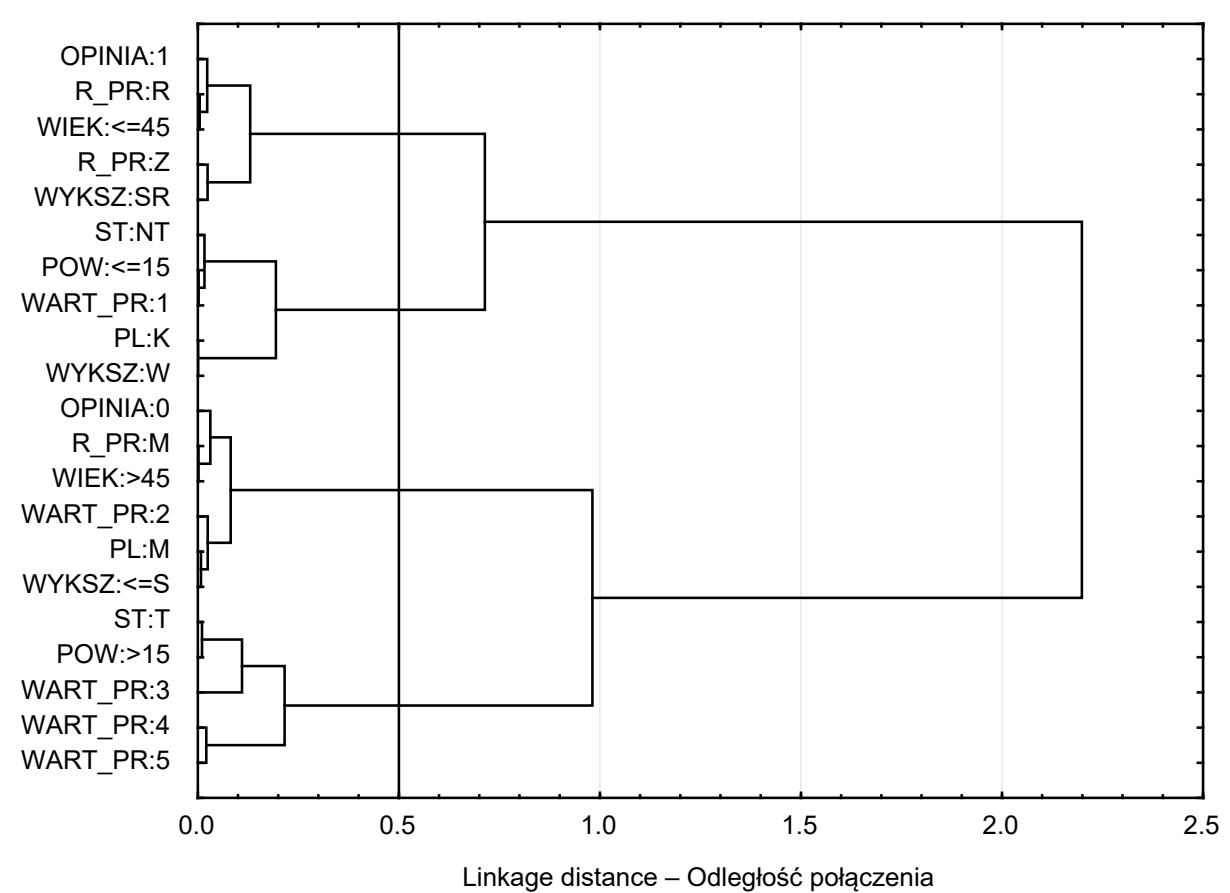

Fig. 3. Dendrogram of the division of feature categories with the aid of the Ward's method with square distance Source: own calculations.

Rys. 3. Dendrogram podziału kategorii cech za pomocą metody Warda z kwadratową odległością

Źródło: obliczenia własne.

degrees, who run non-commercial farms with acreage being not greater than 15 hectares and production levels below PLN 30 thousand, do not indicate an opinion on the bank (neither important nor less important) as the cause for the selection of banking products and services.

The analysis also demonstrated that certain feature categories are not connected with the factor examined that has an influence on the selection of banks by farmers. This concerns such categories as: farms of a commercial status, with the acreage over 15 hectares and the production value of over PLN 30 thousand.

\section{CONCLUSIONS}

The research carried out in the Middle Pomeranian region demonstrated that for farmers, when they choose banking products and services, the following were of the greatest importance in the following order: an opinion about the bank, the bank's reputation and credibility, the speed and promptness of settlements. The amount of fees and commissions and long-standing cooperation with the bank were also of a great significance.

The most frequently indicated choice determinant was selected for the purpose of the research, and an attempt was made to answer the question as to what features characterize farmers for whom the opinion on the bank is the most essential one in terms of the selection of a financial institution. The multidimensional compliance analysis applied permitted a graphical presentation of the structures of answers expressed by the frequency of the occurrence of the individual feature categories, and it enabled the author to formulate conclusions. The analysis demonstrated that those farmers polled who think that the opinion on the bank constitutes an important cause in the selection of banking products and services are in aged below 45, they possess secondary agricultural education and run farms with plant and animal production. 


\section{REFERENCES}

Alessandrini, P., Presbitero, A. F., Zazzaro, A. (2009). Global Banking and Local Markets: A National Perspective. Camb. J. Reg. Econ. Soc., 2, 2, 173-192.

Greenacre, M. (1984). Theory and applications of correspondence analysis. London: Academic Press.

Greenacre, M. (1992). Correspondence analysis in medical research. Stat. Method. Med. Res., 1, 97-117.

Kata, R. (2003). Rola banków spółdzielczych w finansowaniu rolnictwa regionu podkarpackiego. Rzeszów: Uniwersytet Rzeszowski. Wyd. Oświatowe FOSZE.

Kata, R. (2010). Korzystanie przez rolników i przedsiębiorców wiejskich z usług bankowych - analiza preferencji i ograniczeń. Zag. Ekon. Roln., 1(322), 143-162.

Kata, R. (2011). Korzystanie z usług bankowych przez rolników indywidualnych w Polsce. J. Agribus. Rural Dev., 4 (22), 87-99.

Machowska-Szewczyk, M., Sompolska-Rzechuła, A. (2012). Wielowymiarowa analiza zgodności wyników badania ankietowego. Wiad. Stat., 4, 1-16.

Malina, A. (2004). Wielowymiarowa analiza przestrzennego zróżnicowania struktury gospodarki Polski według województw. Kraków: Wyd. AE w Krakowie.

Neville, B. A., Bell, S. J., Mengüç, B. (2005). Corporate reputation, stakeholders and the social performance - financial performance relationship. Eur. J. Market., 39, 9/10, 1184-1198.
Panek, T. (2009). Statystyczne metody wielowymiarowej analizy porównawczej. Szkoła Główna Handlowa w Warszawie: Warszawa.

Paxford, B. (2010). Ryzyko reputacyjne. Bank, 12, 30-31.

Rosa, A. (2014). Rolnicy Pomorza Środkowego na rynku usług bankowych. W: D. Zawadzka, J. Sobiech (Eds.), Wzrost i alokacja aktywów finansowych i rzeczowych rolników (przedsiębiorstw rolniczych i gospodarstw domowych) Pomorza Środkowego (p. 229-260). Wyd. Politechniki Koszalińskiej: Koszalin.

Saxton, M. K. (1998). Where do Reputations Come From? Corp. Reput. Rev., 1, 4, 393-399.

Stanimir, A. (2005). Analiza korespondencji jako narzędzie do badania zjawisk ekonomicznych. Wrocław: Wyd. AE we Wrocławiu.

Stanisz, A. (2015). Co można wycisnąć z tych danych? Retrieved Nov 10th 2015 from: http://www.statsoft.pl

Ward, J. H. (1963). Hierarchical grouping to optimize an objective function. J. Am. Stat. Assoc., 58, 301, 236-244.

Zając, S. (2010). Banki spółdzielcze i ich rola w wielofunkcyjnym rozwoju obszarów wiejskich. W: M. Ruda (Ed.), Uczelnia dla gospodarki - gospodarka dla uczelni (p. 1520). Krosno: Wyd. PWSZ w Krośnie.

Zawadzka, D. (2008). Pomorze Środkowe - społeczeństwo, wieś, gospodarka. Wybrane problemy. Koszalin: Wyd. PTE.

\section{ZNACZENIE REPUTACJI BANKU PRZY WYBORZE PRODUKTÓW BANKOWYCH W OPINII ROLNIKÓW Z POMORZA ŚRODKOWEGO}

Streszczenie. Rolnicy, dokonując wyboru banku, z usług którego chcą korzystać, kierują się różnego rodzaju czynnikami. Celem przeprowadzonego badania był wybór najistotniejszych czynników determinujących wybór banku oraz identyfikacja powiązań między opinią o banku (jego reputacją) a wybranymi cechami charakteryzującymi rolników z regionu Pomorza Środkowego. Do realizacji podjętego celu wykorzystano dane pierwotne pozyskane w toku przeprowadzonych terenowych badań empirycznych oraz wielowymiarową analizę korespondencji. Zestaw zmiennych niezależnych stanowiły: status oraz powierzchnia gospodarstwa rolnego, rodzaj i wartość produkcji, płeć, wiek oraz wykształcenie kierującego. Jak wynika z przeprowadzonych badań, najistotniejszą wskazywaną determinantą wyboru banku przez rolników była opinia o banku (jego reputacja). Analiza wykazała między innymi, że ankietowani rolnicy, którzy uważają, że opinia o banku jest ważnym czynnikiem przy wyborze produktów i usług bankowych, są w wieku poniżej 45 lat, mają wykształcenie średnie rolnicze i prowadzą gospodarstwa z produkcją roślinną lub zwierzęcą.

Słowa kluczowe: rolnik, produkty i usługi bankowe, opinia o banku, reputacja i wizerunek, Pomorze Środkowe 